Bolm Inst. oceanogr., S Paulo, 26:11-19, 1977

\title{
A NEW DEEP SEA SPECIES OF BATHYGNATHIA (ISOPODA, GNATHIIDEA) FROM THE WESTERN SOUTH ATLANTIC OCEAN
}

\author{
PLINIO SOARES MOREIRA
}

Instituto Oceanográfico da Universidade de são Paulo

\section{SYNOPSIS}

Bathygnathia magnifica sp.n.,a new bathyal species of Gnathiidea (Crustacea, Isopoda), is described for science. It was collected from off southern Brazil, at $387 \mathrm{~m}$ depth. The present find seems of interest, not only because for the first time a species of Bathygnathia is reported at such a depth, but because it is the first species of the genus bearing eyes, in spite of depauperate.

\section{INTRODUCT ION}

The aim of this paper is to report on the occurrence of a new bathyal isopod species, namely Bathygnathia magnifica sp. n., from the Western South Atlantic Ocean. The new species was collected from off southern Brazil, at a depth of 387 meters.

PUBL. NO 388 DO INST. OCEAN. DA USP. 
Bathygnathia magnifica sp. n.

(Figs 1-17)

HOLOTYPE - Adult male, $7.3 \mathrm{~mm}$ long. Plínio Soares Moreira col.

TYPE LOCALITY - St. MBT 117. Off State of Santa Catarina, Brazil, $28^{\circ} 03^{\prime} \mathrm{S}, 47^{\circ} 09^{\prime} \mathrm{W}, 387 \mathrm{~m}$ depth. June, 1970.

ETYMOLOGY - The species name is derived from the Latin word magnificus = magnificent, alluding to the size of the specimen.

DESCRIPTION - Body (Fig. 1) - Holotype male - Elongate, a little more than 4 times longer than broad, lateral margins with short setae. Colour light yellowish; pereon yellowish-brown especially on pereonites IV-V; mandibles milky white, apically transparent.

Head - Longer than broad (lenght 1.2 times width, rostrum not included); lateral margins even and rounded, posterior margin convex; sides thick and convex, mid-dorsal surface distinctly depressed, posteriorly slightly convex; frontal margin prolonged into an elongate, grossly triangular rostrum with margins straight and apex rounded, and with a sub-apical tuft of short setae; head 1.6 times length and 1.4 times width of rostrum. Eyes located antero-laterally on head, oval, not prominent, light yellowish in colour.

Pereon - Shaped as shown in Figure 1. Dorsum smooth, without tubercles or ridges, with fine setae on lateral margins. Pereonite I very narrow, with a snall postero-lateral prominence. Pereonites II and III 1arger than 1st, 3rd longer than 2nd, both with lateral margins curved, and antero-1ateral angles projected slightly forward. Pereonites IV to VI much larger than preceding pereonites. Pereonite IV divided dorsally by a straight mid-1ongitudinal line. Pereonite V about 1.4 times length of IV, dorsum divided by two transversal semilunar lines extending to lateral margins. Pereonite VII of reduced size. 
Pleon - Dorsally convex, smooth; pleural plates of each pleonite slight1y depressed, fringed by short setae, ending in a point. Telson triangular, apically pointed.

Antenna 1 (Fig. 2) - Small, curved, with flagellum not reaching to end of peduncular article 3 of antenna 2. Peduncle composed of 3 articles; article 2 subequal to article 1 , covered by scattered fine setae, outer margin shallowly concave, inner margin convexly prominent and bearing both 1 well developed broom seta and 1 simple seta; article 3 elongate, pronouncedly curved, about 1.5 times length of $2 \mathrm{nd}$, with unequal slender setae which are longer on distal part of article. Flagellum 5-articulate; 1st article reduced; last 3 articles with 1 single aesthete on distal angle (Fig. 3); penultimate article 1.4 times length of terminal one.

Antenna 2 (Fig. 4) - Elongate, reaching to a level beyond apex of rostrum. Peduncle 4-articulate; articles 1 and 2 deprived of setae, the 2 nd smaller; article 3 the longest of peduncle, almost 1.4 times length of $4 \mathrm{th}$, with slender setae scattered along the article and on its distal part; article 4 distinctly widening posteriorly, with a number of slender setae distally. Flagellum composed of 8 articles progressively narrowing towards apex; penultimate article about 1.4 times length of terminal one (Fig. 5), which ends in a tuft of unequal simple setae.

Mandibles - Dorsal view (Fig. 1) - narrow, curved inwards, reaching distally to a level well forward tip of rostrum; apex narrow, pointedrounded, not obliquely truncate; margins smooth, without notch or teeth. Lateral view (Fig. 6) - proximally broader, narrowing towards a pointedrounded apex; dorsal margin even and curved; ventral margin with a pronounced, hyaline, irregularly convex laminar expansion projected downwards and forwards.

Maxilliped (Fig. 7) - Basis well developed, strong, thick, with outer margin pronouncedly convex, inner shallowly concave, both setose. Endite narrowing towards apex, inner margin distally with many-toothed coupling hooks (Fig. 8). Palp 4-articulate; inner margin of all articles setose, outer margin with moderately elongate plumose setae; first 2 articles broad, 
longer than remainder ones; 3rd the smallest of palp, almost quadrate; 4th about 1.5 times length of 3 rd, apex pointed-rounded.

Pylopod (Fig. 9) - Elongate, operculiform, covering the mouth appendages, reaching distally to apex of rostrum; outer distal surface with an irregular, longitudinal row of short setae, margins fringed by fine setae. It is composed of 4 articles. Article 1 narrowly-elongate, proximal margin widely rounded. Article 2 the largest of pylopod, broader proximally, about 2.8 times length of $1 \mathrm{st}$, and 3.8 times length of last two articles together; outer margin concave, inner nearly straight; proximal inner angle widely rounded with 5 broom setae, proximal outer angle with 2 simple setae. Article 3 narrow, elongate, about 3 times longer than broad. Article 4 minute, of semilunar shape (Fig. 10).

Pereopods I, II and $V$ (Figs 11, 12, 16) - Similar one to another, and markedly different from pereopods III-IV. Margins and lateral surface of articles with many unequal, slender simple setae, which are longer on basis and ischium. Ischium with sides parallel, without disto-lateral projection. Ischium, merus and carpus not tuberculated. Dactylus curved, tipped by 1 blunt claw.

Pereopod I (Fig. 11) - Basis about 0.8 times length of carpus and propodus together. Ventral margin of merus and carpus each with 1 stout seta distally, that of propodus with 2 setae, one medial and one distal. Propodus narrow and elongate, about 0.8 times length of carpus.

Pereopod II (Fig. 12) - Number and pattern of stout setae on ventral margin of merus, carpus and propodus as on pereopod I.

Pereopod V (Fig. 16) - Basis about 2.2 times length of carpus and propodus together. Ventral margin of merus without stout setae, that of carpus and propodus with 2 stout setae. Propodus about 1.4 times length of carpus .

Pereopods III and IV (Figs 13, 15) - Similar one to another. Stouter than pereopods I, II and V. Margins and surface of articles with many unequal setae slightly stronger than on preceding pereopods. Ischium with a 
strong, very characteristic laterodistal projection. Ischium, merus and carpus, ventral margin and distal portion tuberculate, with each tubercle bearing 1 apical seta.

Pereopod III (Fig. 13) - Basis about 1.9 times length of carpus and propodus together. Carpus with 1 stout seta on ventral margin. Propodus devoid of such stout seta.

Pereopod IV (Fig. 15) - Carpus with 2 stout setae on ventral margin. Propodus without stout seta.

Pleopod 2 (Fig. 17) - Protopod transversely elongate, broad, margins densely setose; inner margin bearing 1 single plumose coupling seta; outer margin widely rounded with 1 simple seta. Exopod smaller than endopod, slightly widening posteriorly; distal margin fringed by plumose setae; inner and outer margins densely setose. Endopod slightly narrowing distally; rear margin bordered by plumose setae; outer margin naked, inner densely setose.

Uropods - Biramous. Exo- and endopod elongate, fringed by setae, reaching to a level beyond apex of telson.

REMARKS - Bathygnathia magnifica sp. n. is easily distinguished from other species of the genus (Monod, 1926; Birstein, 1963; Ca1s, 1974) by the presence of depauperate eyes, and by the characteristic shape of the mandibles.

Indeed, the narrow mandibles with its smooth outer margins and pointed apex, readily separate $B$. magnifica sp. n. from all described Bathygnathia species. Important additional characteristic of the new species is also the shape of each pereonite I-VI.

It is noteworth in $B$. magnifica sp. $\mathrm{n}$. the yellowish, depauperate eyes. This is the first species within the genus with distinct eyes. A11 remainder species assigned to the genus are blind.

It seems also remarkable the occurrence of a Bathygnathia species at 387 meters depth. The available data on depth occurrence for species of Bathygnathia are from depths below 700 meters. 


\section{RESUMO}

Uma nova espécie de Gnathiidea (Crustacea, Isopoda) batial, Bathygnathia magnifica sp. n., è descrita para a ciência. Foi coletada ao largo da região centro-sul do Brasil, a $387 \mathrm{~m}$ de profundidade. A presente espécie destaca-se das demais do gênero, que são cegas, pela presença de olhos depauperados, de coloração amarelada. Pela primeira vez, também, uma espécie de Bathygnathia é coletada a tal profundidade. Todas as demais descritas ocorrem em profundidades maiores do que 700 metros.

\section{REFERENCES}

BIRSTEIN, J.A. 1963. Deep-sea isopods of the North-Western Pacific. Issled. Akad. Nauk. U.S.S.R.,:1-124, pls 1-3.

CALS, P. 1974. Gnathiides de 1'Atlantique Nord. II. Description de Bathygnathia monodi n. sp., gnathiide (Crustacea, Isopoda) bathyal du Golfe de Gascogne. Étude de l'hétérogénéité métamérique des métamères péréiaux. Cah. Biol. mar., 15(3):409-430.

MONOD, Th. 1926. Les Gnathiidae. Essai Monographique (morphologie, biologie, systématique). Mém. Soc. Sci. nat. Maroc. (13):1-667, 1 pl.

(Recebido em 30/Maio/1975) 

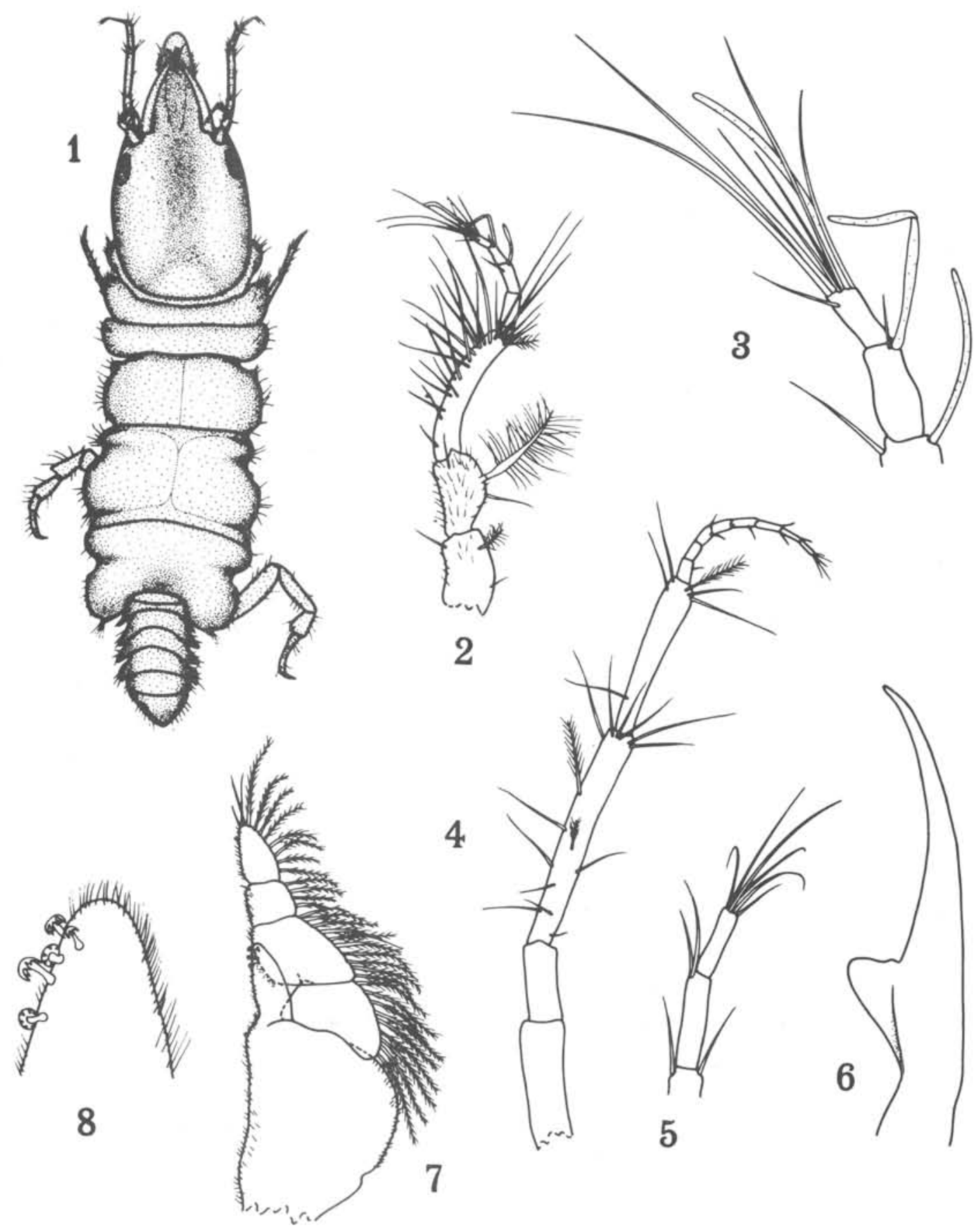

4
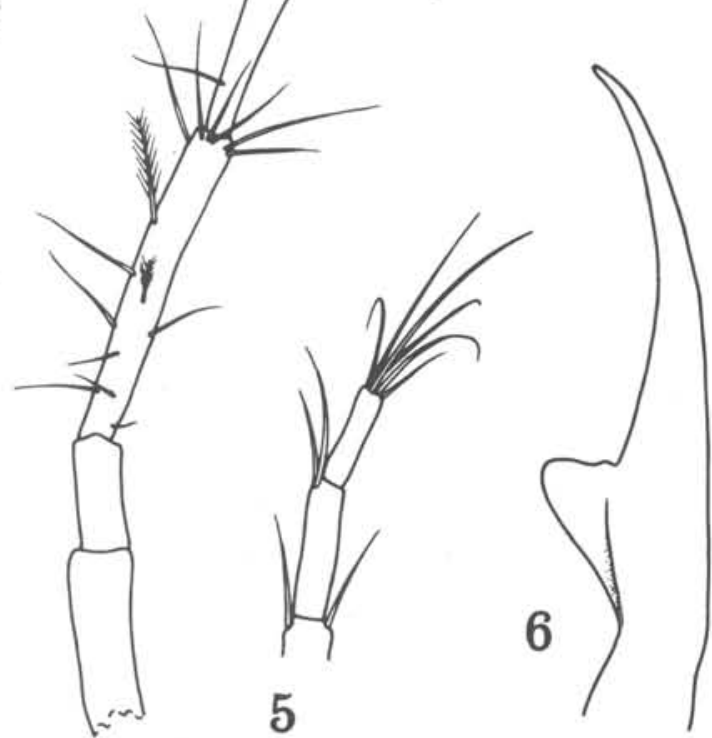

Figs 1-8 - Bathygnathia magnifica sp. n., holotype adult male, $7.3 \mathrm{~mm}$ long.

Fig. 1 - Whole animal, dorsal view.

Fig. 2 - Antenna 1.

Fig. 3 - Antenna 1, apex of flagellum.

Fig. 4 - Antenna 2.
Fig. 5 - Antenna 2, apex of flagellum. Fig. 6 - Mandible, lateral view.

Fig. $?$ - Maxilliped.

Fig. 8 - Maxilliped, apex of endite. 


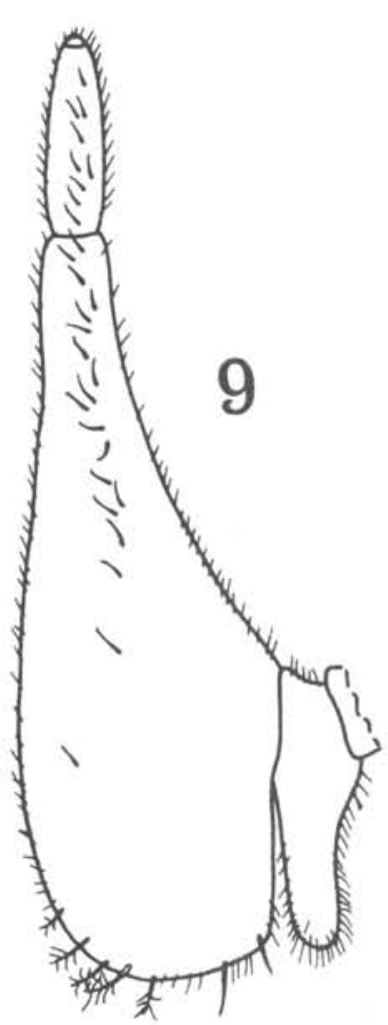

10

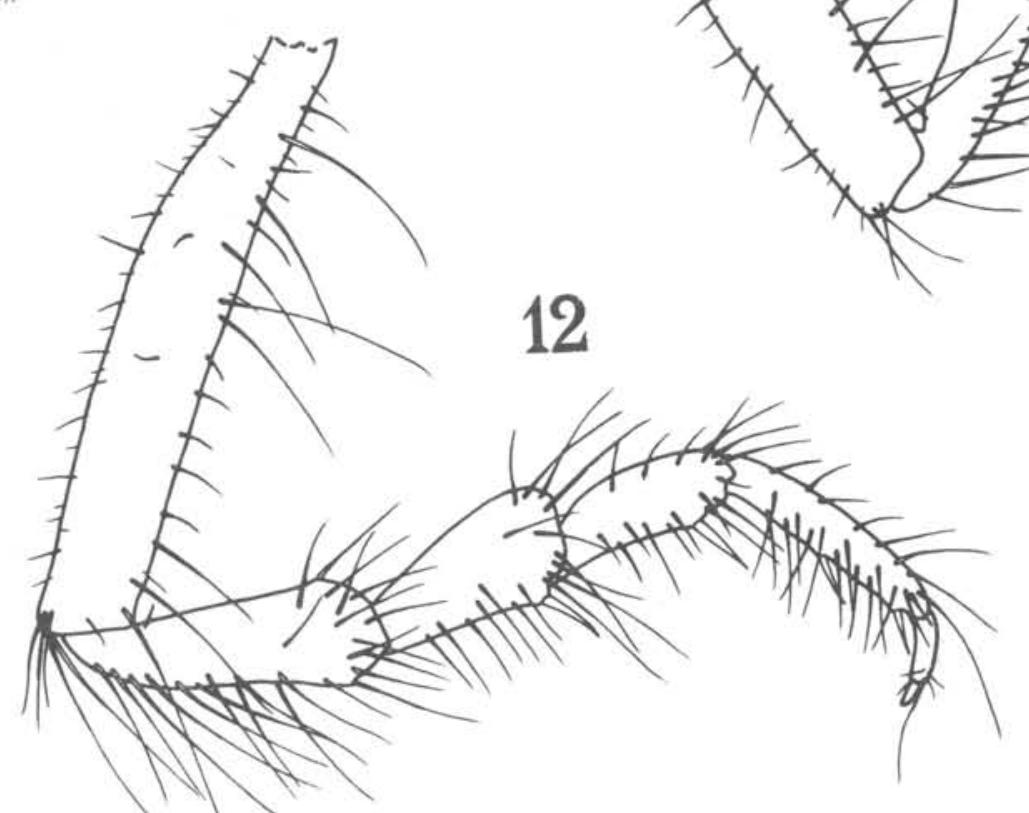

Figs 9-12 - Bathygnathia magnifica sp. n., holotype adult male, $7.3 \mathrm{~mm}$ long.

Fig. 9 - Pylopod.

Fig. 10 - Pylopod apex.

Fig. 11 - Pereopod 1.

Fig. 12 - Pereopod II. 


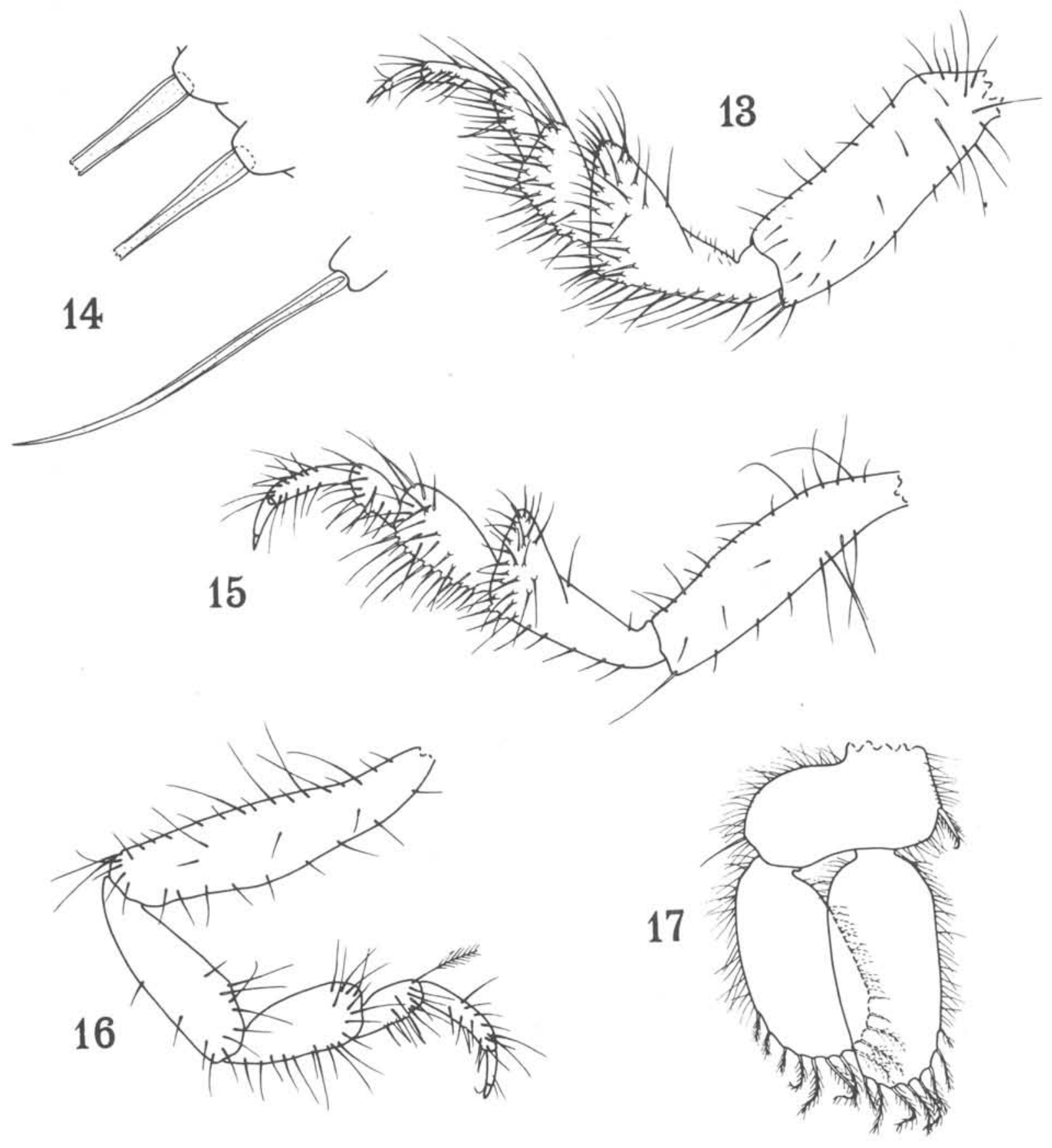

Figs 13-17 - Bathygnathia magnifica sp. n., holotype adult male, $7.3 \mathrm{~mm}$ long.

Fig. 13 - Pereopod 111.

Fig. 14 - Pereopod 111 , tubercles on ischium through to propodus.

Fig. 15 - Pereopod IV.

Fig. 16 - Pereopod V.

Fig. 17 - Pleopod 2. 